\title{
T and B lymphocyte markers in effusions of patients with non-Hodgkin's lymphoma
}

\author{
AS KRAJEWSKI, AE DEWAR, EF RAMAGE \\ From the Department of Pathology, University of Edinburgh, Medical School, Teviot Place, \\ Edinburgh EH89AG
}

SUMmary $\mathrm{T}$ and $\mathrm{B}$ cells were sought in effusion fluids of 13 patients with lymphoma. In $\mathrm{T}$ cell lymphomas (four cases) morphologically abnormal cells that formed $\mathrm{E}$ rosettes were present. In B cell lymphomas (nine cases) morphologically abnormal cells were present in only two cases, however immunological studies showed a reduction in $\mathrm{T}$ cells and monoclonal light chain immunoglobulin expression in six of nine cases.

Patients with lymphocytic effusions often present a diagnostic problem. In particular the distinction of neoplastic from inflammatory lymphoid infiltrates may be difficult.' In only about $10 \%$ of effusions from patients with lymphoma can abnormal cells be detected by cytological examination.' Recently Domagala et $a l^{3}$ have suggested that $T$ and $B$ lymphocyte enumeration may be useful in the diagnosis of lymphomatous infiltrates in effusions. In this report we give the results of studies on $T$ and $B$ lymphocytes in effusions of 13 patients with nonHodgkin`s lymphoma.

\section{Material and methods}

Pleural or ascitic effusions were obtained from patients undergoing diagnostic taps or drainage for relief of symptoms. A total of 13 patients with lymphoid malignancy were studied. In cases 1-12 diagnoses were made by lymph node biopsy. In case 13 diagnosis was made by haematological examination of blood and bone marrow. A control group of six patients with non-lymphoid malignancy was also studied (two lung carcinoma, one metastatic seminoma, one pneumonia, one pulmonary embolus, one pericarditis). Samples were collected into sterile plastic universal containers containing EDTA (2\%) or heparin (10 $\mathrm{U} / \mathrm{ml})$. Mononuclear cells were separated from effusion fluids by centrifugation over Ficoll-Hypaque. Mononuclear cells from the effusion Ficoll interface were washed twice in TC 199 (Flow Laboratories). (ytospin preparations were made for routine morphological assessment (May-GrünwaldGiemsa stains) and cytochemistry (non-specific esterase, acid phosphatase and chloroacetate esterase). T cells were identified by rosetting with sheep red blood cells and B cells by immunofluorescent staining with anti-human IgM, kappa and lambda antisera. ${ }^{45}$

\section{Results}

The results of immunological studies on effusions are shown in the Table.

In cases of $T$ cell lymphoma morphologically abnormal lymphoid cells were present in effusions of all the cases examined. Cases 1-3 were diagnosed as lymphoblastic lymphoma of $\mathrm{T}$ cell type on the basis of clinical features and histological and immunological investigations of lymph node, blood and bone marrow. In cases 1, 2 and 3 neoplastic lymphoblastoid cells in effusions formed $\mathrm{E}$ rosettes and exhibited focal acid phosphatase activity (Figs. 1,2). Case 4 was diagnosed as an immunoblastic lymphoma by lymph node biopsy. In pleural fluid large immunoblastic cells that formed $\mathrm{E}$ rosettes were seen (Fig. 3).

In cases 5-12 diagnosis was established by histological examination of lymph nodes and immunological studies of lymph node and blood mononuclear cells. These were all B cell neoplasms. Of the B cell lymphomas, in only two cases (cases 5 and 7) did the effusion contain morphologically abnormal lymphoid cells. In case 5 these were large non-cleaved lymphoid cells (Fig. 4). In case 7 typical cleaved cells were present (Fig. 5). In both cases the neoplastic cells exhibited monoclonal surface immunoglobulin. In the other cases the effusions contained morphologically normal small lymphocytes. However even in these cases immunological investigations of the effusions showed an increased 
$T$ and $B$ lymphocytes in effusions

\begin{tabular}{|c|c|c|c|c|c|c|}
\hline \multirow[t]{2}{*}{ Patient } & \multirow[t]{2}{*}{ Diagnosis } & \multicolumn{2}{|c|}{ \% of lymphocytes } & \multicolumn{3}{|c|}{ Light chain expression } \\
\hline & & $E^{+}$ & $\operatorname{slg} M^{+}$ & $\overline{\kappa+}$ & $\lambda^{+}$ & \\
\hline 1 & Lymphoblastic lymphoma & 92 & - & - & - & \\
\hline 2 & 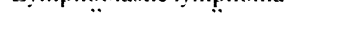 & 76 & 1.5 & () & 0 & \\
\hline$\overline{3}$ & .* & 83 & 6.0 & 4 & 5 & Polvclonal \\
\hline it & Immunoblastic lymphoma & 58 & 18.5 & 12 & 20 & Polyctonal \\
\hline 5 & Centroblastic lymphoma & 56 & $57 \cdot 0$ & 0 & 29 & $\lambda$ \\
\hline 6 & Centrocytic - diffuse & 59 & 47.5 & $21 \cdot 5$ & $45 \cdot 5$ & $\hat{\lambda}$ \\
\hline 7 & - diffuse & 9 & $72 \cdot 0$ & 18 & 46 & $\hat{\lambda}$ \\
\hline 8 & - diffuse & 19 & $24 \cdot 0$ & 52 & 5 & $\hat{\kappa}$ \\
\hline$y$ & - follicular & (1) & $64 \cdot 0$ & 24 & 62 & $\ddot{\lambda}$ \\
\hline 10 & - follicular & 92 & 14.5 & $-3 \cdot 5$ & $6 \cdot 0$ & Polvclonal \\
\hline 11 & - follicular & 85.5 & 1.5 & i. & 1.5 & Polvclonal \\
\hline 12 & $\cdots \quad-$ follicular & $88 \cdot 5$ & $32 \cdot()$ & 33 & $20^{\circ}$ & Polyclonal \\
\hline & Chronic lymphocytic leukaemia & 22 & $22 \cdot 0$ & & & \\
\hline Controls & $\begin{array}{l}(n=6) \text { Mean } \pm S D \\
R \text {. }\end{array}$ & $84 \pm 13$ & $4 \cdot 5=2$ & $10 \pm+$ & $6 \pm 2 \cdot 5$ & Polyclonal \\
\hline
\end{tabular}

Cases 7,11 were ascitic fluids, the remainder were pleural fluids. Monoclonality of light chain expression was determined from calculation of $\kappa: \lambda$ ratio. A $\kappa: \lambda$ ratio of $>4: 1$ or $\lambda: \kappa$ of $>2: 1$ was considered abnormal $(5,6)$.

number of $B$ cells with monoclonal light chain expression, and a reduced number of $\mathrm{T}$ cells in all but three cases. In these three cases $(10,11,12)$ all of follicular lymphoma, B cells showed polyclonal staining with light chain antisera, and normal numbers of $T$ cells. One case of chronic lymphocytic leukaemia (case 13) showed reduced T cells in pleural effusion with a monoclonal B cell population.

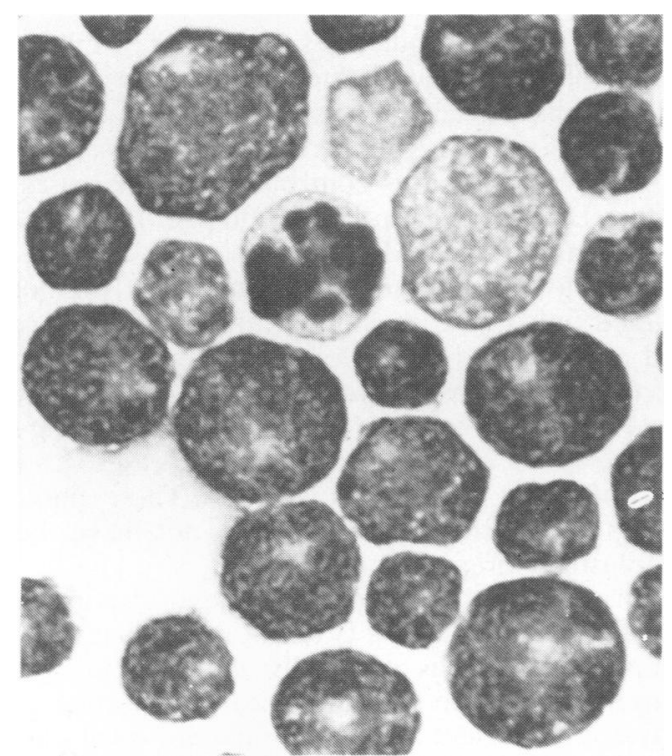

Fig. 1 Effusion cells from case 3 showing large lymphoblastic cells, some with convoluted nuclei. Cytospin preparation stained with May-Grünwald-Giemsa. Original magnification $\times 1000$

\section{Discussion}

Although in this study only a small number of cases have been examined the data show the potential of immunological assessment of effusion cells for the diagnosis and immunological typing of nonHodgkin's lymphoma and the distinction between lymphomatous and other lymphocytic infiltrates.

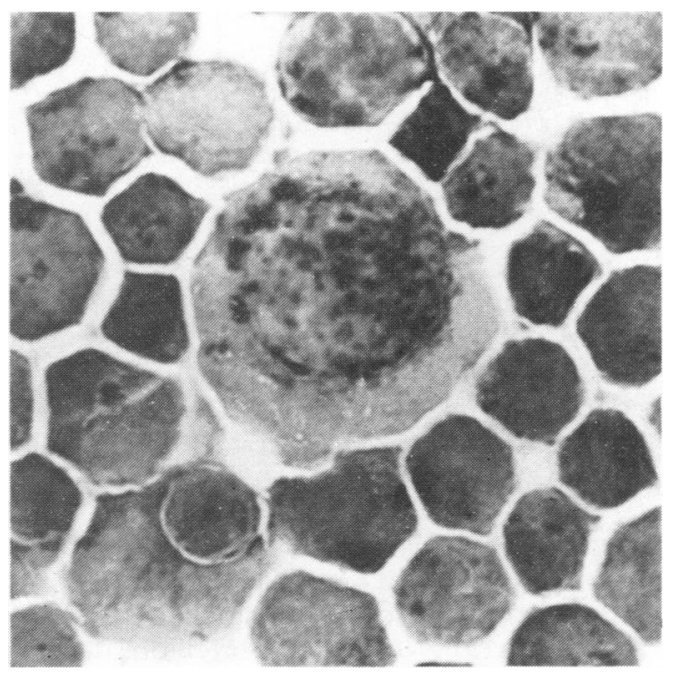

Fig. 2 Effusion cells from case 3 showing focal acid phosphatase staining in lymphoblasts and strong perinuclear staining in a serosal cell. Cytospin preparation stained for acid phosphatase. Original magnification $\times 1000$ 


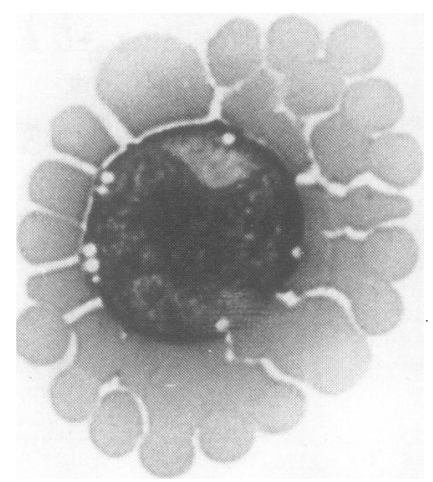

Fig. 3 Effusion cell from case 4 showing a large immunoblastic cell forming an E rosette. Cytospin preparation stained with May-Grünwald-Giemsa. Original magnification $\times 1000$

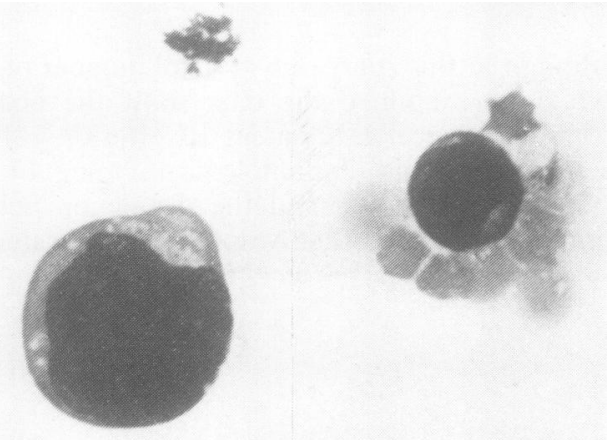

Fig. 4 Effusion cells from case 5 showing (left) a large neoplastic lymphoid cell with cytoplasmic vacuolation and (right) a normal small lymphocyte forming an E rosette. Cytospin preparation stained with May-Grünwald-Giemsa. Original magnification $\times 1000$

In non-lymphomatous effusions the predominant lymphoid cell is a morphologically normal $T$ lymphocyte with a small percentage of $B$ cells. The percentages of $\mathrm{T}$ and $\mathrm{B}$ lymphocytes in the control group in this study are similar to those previously reported. ${ }^{378}$

In patients with $T$ cell lymphoma normal percentages of $T$ cells were present, these however were morphologically abnormal in all the cases examined. In two cases of lymphoblastic lymphoma $(2,3)$ effusion cells showed high levels of Tdt activity further indicating an immature abnormal $\mathrm{T}$ cell population. ${ }^{9}$ In cases of $\mathrm{T}$ cell lymphoma less than $20 \%$ of the lymphocytes expressed surface immunoglobulin.

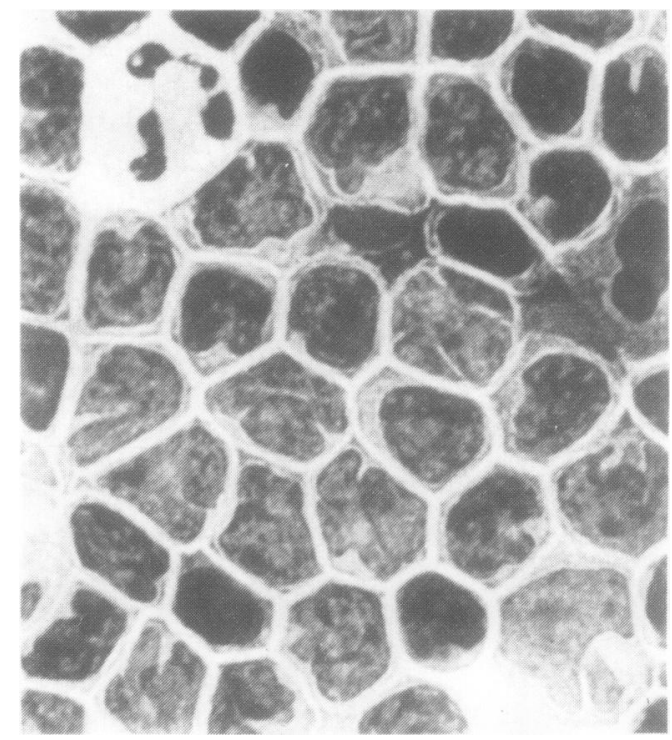

Fig. 5 Effusion cells from case 7 showing numerous cleaved cells (centrocytes). Cytospin preparation stained with haematoxylin. Original magnification $\times 1000$

All cases of non-follicular B cell lymphoma showed a reduction in the percentage of $T$ cells and increased B cells with monoclonal light chain expression, even in the absence of morphologically abnormal cells. These findings are similar to those of Domagala et al ${ }^{3}$ who in a study of four cases of chronic lymphocytic leukaemia and one centrocytic lymphoma found no morphologically abnormal cells but a marked reduction in $\mathrm{T}$ cells and increase in B cells compared to non-lymphomatous controls. In all the cases of diffuse B cell lymphoma we found over $20 \%$ of cells expressing surface IgM.

In the four cases of follicular centrocytic lymphoma studied only one case showed a reduction of $T$ cells and an increased monoclonal B cell population. In the three other cases normal numbers of $T$ cells were present, with B cells showing polyclonal staining for surface Ig. In only one of these three cases was the percentage of B cells above $20 \%$. These findings suggest that the effusions may not have been neoplastic in origin.

This study has established that identification of $T$ and B cells in effusions is useful in the diagnosis of lymphoma. This is especially the case in B cell lymphomas where morphologically abnormal cells may not be present but where immunological studies may clearly show evidence of a neoplastic infiltrate in effusion fluid. In patients with known lymphoma the distinction by immunological methods between lymphomatous and other infiltrates in effusion fluids 
may be of importance not only in staging of disease but also in subsequent clinical management.

We are grateful to the physicians of the Edinburgh Lymphoma Group for supplying the effusion fluids. The work was done under the auspices of the Edinburgh Lymphoma Group in the Department of Pathology, Edinburgh University. The authors are indebted to Miss J Kidby and Mr JK Rae for technical assistance.

\section{References}

' Weick JK. Kiely JM, Harrison EG, Carr DT, Scanlon PW. Pleural effusion in lymphoma. Cancer 1973;31:848-53.

2 Storey DD. Dines DE, Coles DT. Pleural effusion: A diagnostic dilemma. JAMA 1976;236:2183-6.

'Domagala W. Emeson EE, Koss LG. T and B lymphocyte enumeration in the diagnosis of lymphocyte rich pleural fluids. Acta Cytol 1981:25:108-10.
4 Dewar AE, Krajewski AS, Marray J. T-cell lymphoma in children and young adults: Clinical, immunological and pathological features. Br J Cancer 1980;42:659-67.

5 Krajewski AS, Dewar AE. Studies on blood lymphocytes of patients with nodular poorly differentiated lymphocytic lymphoma. J Clin Pathol 1981;34:896-901.

- Garrett JV, Scarffe JH, Newton RK. Abnormal peripheral blood lymphocytes and bone marrow infiltration in non-Hodgkin's lymphoma. Br J Haematol 1979;42:41-50.

' Manconi PE. Fadda MF, Cadoni A, Cornaglia P, Zaccheo D, Grifoni V. Subpopulations of T lymphocytes in human extravascular fluids. Int Arch Allergy Appl Immunol 1978; 56:385-90.

* Pettersson T, Klockars M, Hellstrom PE, Riska H, Wangel A. $\mathrm{T}$ and $\mathrm{B}$ lymphocytes in pleural effusions. Chest 1978;73:49-51.

- Greaves MF. Analysis of the clinical and biological significance of lymphoid phenotypes in acute leukaemia. Cancer Res 1981; 41:4752-66.

Requests for reprints to: Dr AS Krajewski, Department of Pathology, University Medical School, Teviot Place, Edinburgh EH8 9AG, Scotland. 